\title{
Analysis of the potential contamination risk of groundwater resources circulating in areas with anthropogenic activities
}

\author{
M. Spizzico, N. Lopez, and D. Sciannamblo \\ Dept. of Civil and Environmental Engineering, Polytechnic University of Bari, Italy \\ Received: 30 July 2004 - Revised: 19 October 2004 - Accepted: 28 December 2004 - Published: 21 January 2005 \\ Part of Special Issue "Natural and anthropogenic hazards in karst areas"
}

\begin{abstract}
The area investigated is located in the province of Brindisi (Italy). It is a generally flat area separated from the nearby carbonatic plateau of the Murgia by quite indistinct and high fault scarps. As regards the geological features, carbonatic basement rocks and post-cretaceous terrains made up of calabrian calcarenites and middle-upper Pleistocenic marine terraced deposits can be distinguished.
\end{abstract}

In the examined area there are two different hydrogeological environments. The first is represented by deep groundwater, the main groundwater resource in Apulia.

The second hydrogeological environment, now of lesser importance than the deep aquifer in terms of size and use, is made up of some small shallow groundwater systems situated in post-calabrian sands and located in the eastern area.

During some sampling cycles carried out in the studied area, water was withdrawn from both the deep aquifer and from the shallow groundwater. For every sample, the necessary parameters were determined for the physical and chemical characterisation of two different hydrogeological environments. Moreover, some chemical parameters indicating anthropogenic activities were determined.

Analysis of the aerial distribution of the measured parameters has shown some main areas subject to different conditions of contamination risk, in accordance with the hydrogeological and geological features of the investigated area.

In the south-eastern part of the investigated area, the important action performed by the surface aquifer for protecting the deep groundwater from contamination of anthropogenic origin is clear.

On the other hand, in the shallow groundwater, areas of nitrate and nitrite contamination have been identified, which result from the extensive use of fertilizers.

Correspondence to: M. Spizzico

(m.spizzico@poliba.it)

\section{Introduction}

The aim of this work is to learn the current quality of the water in the deep aquifer in an area where, because of geostratigraphic characteristics, a significant number of surface aquifers run off into it. The area is subject to significant anthropogenic impact, which is concretised with effects on the civil-industrial and even more on agricultural activity.

The study area, which has already been studied from a hydrogeological viewpoint (Tadolini et al., 1994; Sciannamblo et al., 1994; Tadolini et al., 1996), extends to the NE of the municipality of S. Vito dei Normanni in the province of Brindisi (Italy). It is a flat area whose max height is reached in the settlement of S. Vito dei Normanni (108 m a.s.l.) covering about $150 \mathrm{~km}^{2}$ and delimited by the Adriatic coastline, "Canale Giancola", a portion of State Highway no. 16, and the road S. Vito dei Normanni - Punta Penna Grossa.

In the northern part, behind the coast there is a morphologically depressed area where groundwater springs form marsh grounds making up the wet land of Torre Guaceto, that is a State nature reserve of great historical importance.

The surface hydrography is rather small, runoff discharge to the sea mainly takes place by means of natural rills, including the main one, "Canale Reale", which, at sites, often receives waste water from towns and farms along its course.

The anthropogenic and production activities of the area under investigation depict the social-economic peculiarities of Apulia very well.

Soils, with averagely good physical and fertility characteristics suitable for irrigation and yielding good - high production standards, have greatly favoured the main local anthropogenic practise of Agriculture. Indeed, about $80 \%$ of the whole area is used for vegetable growing whose products have an average resistance to salinity, together with other Mediterranean crops such as olives and vines. There is also animal farming, small greenhouse gardening farms and olive oil production plants.

Several wells have been dug privately to pump groundwater for use in irrigation and home consumption. 


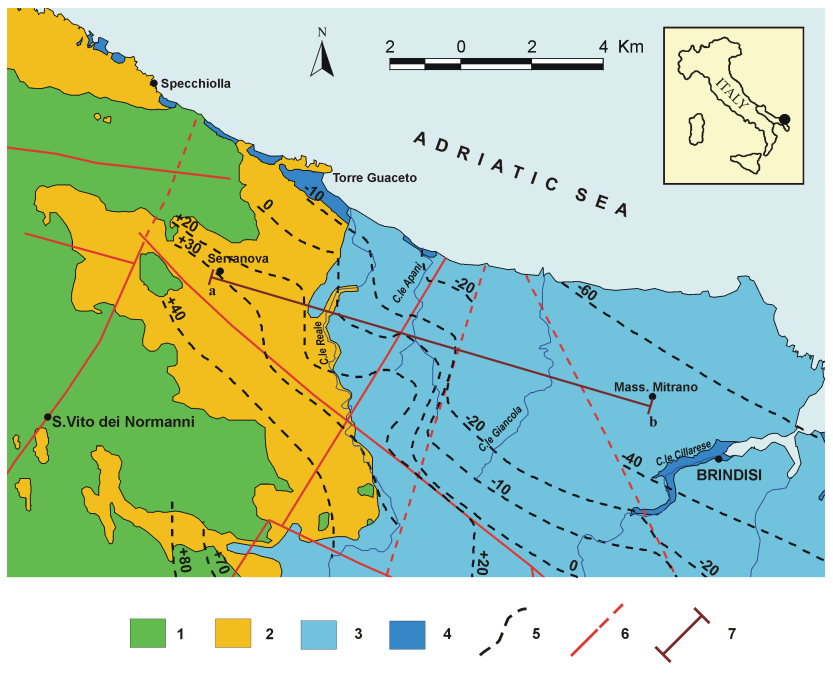

Fig. 1. Distribution of outcropping rocks. Legend: 1) Limestones and dolomitic limestones (Cretaceous); 2) Calcarenites (Lower Pleistocene; 3) Sands with marly clays (Pleistocene); 4) Alluvial and swamp deposits (Holocene); 5) Limestone roof isobaths (in meters a.s.1.); 6) Faults; 7) Geological cross-section.

In order to characterise the Apulian carbonate deep aquifer water quality and to assess the impact of anthropogenic activities on both the deep and the shallow groundwater, hydro chemical data obtained from water samples taken during the last two years, were analysed.

In particular, spatial variations of the adjS.A.R. (Adjusted Sodium Adsorption Ratio) parameter and of the nitrate concentrations were investigated.

\section{Geological, hydrogeological and pedological outline}

The study area belongs to the so-called "Apulian Platform", basically made up of calcareous and calcareous - dolomitic rocks of Cretaceous age. The carbonate basement with NWSE oriented faults, widely outcropping in the south-western zone (Fig. 1), locally degrades reaching an elevation of $-40 \mathrm{~m}$ a.s.l. In this carbonate environment we find the only Apulian groundwater resource defined as a "deep aquifer" which, floating on intruding seawater, flows to the Adriatic Sea with low piezometric gradients (Cotecchia, 1977; Grassi and Tadolini, 1974; Grassi and Tadolini, 1985; Grassi et al., 1977).

The carbonate sequence has uneven and sometimes intense fracturing which varies according to depth. Karst is clearly developed and previous studies (Grassi, 1974; Zezza, 1975; Cotecchia, 1977) have revealed that:

- there is a marked anisotropy in the areal and vertical distribution of surface and subterranean karst forms;

- there is a close relationship between tectonic fractures and karst cavities;
- karst is clearly developed where tectonic fracturing and sea regression and transgression have lead to its formation and development;

- the development of karst phenomena depends on the presence of lithotypes that are unaffected or little affected by karstification;

- "terra rossa" is commonly found within the aquifer's fractures and cavities: this type of paleosoil derives from the development of insoluble residue from carbonate dissolution (Edlman, 1947; Sinno, 1964; Dell'Anna, 1967).

The preferential trends of the horizontal and subhorizontal karst channels coincide with those of the more significant regional and local tectonics systems. It is interesting to note that in the Cretaceous lithofacies the preferential orientation of most karst caves follows the Apennine structural trend $\left(\mathrm{N} 30^{\circ} \mathrm{W}\right)$.

Another important element is that karst systems at different stages of development, and thus endowed with different drainage capacities, occur above and below present mean sea level. This fact explains some of the more or less unexpected spatial variations in permeability, the changes in hydrogeologic parameters and the differences in storage capacity of the aquifer.

One of main factors that has governed the vertical distribution of the karst system has been the repeated variation in the base level of karst activity as a result of relative movements between land and sea since Cretaceous times. As the movements occurred differentially, the ensuing effects on the drainage network vary from area to area (Grassi, 1974).

The movements have resulted in some levels of the Mesozoic being quite strongly karstified, while others show hardly any signs of the phenomena; such levels often lies in welldefined rock horizons or intervals, which, at times, can be correlated with each other and can sometimes be tied in with old shorelines.

In the area, transgressively on the Cretaceous carbonate formation, there are calcarenites of Calabrian age which represent the base of the "Sedimentary cycle of the Bradanic foredeep" (Ciaranfi et al., 1992). They are sediments with a variable cementation degree, sideways and vertical, outcropping in the central part of the studied area, with a thickness not exceeding 20-30 m. A middle-upper Pleistocene formation was found in stratigraphic concordance with the calcarenites. It is made up of yellow sands, characterised by considerable variations of facies and by a base level of marly clays (Fig. 2). In these deposits, found in the south-eastern part of the study area, some $10-20 \mathrm{~m}$ in thickness, there is often a little groundwater of a seasonal nature.

For the groundwater circulation, the marly clay level represents a sort of barrier to the free discharge of the deep aquifer to the sea, forcing it to circulate under confined conditions. Near the calcareous and calcarenite deposits, groundwater circulation is phreatic, except for a limited area 


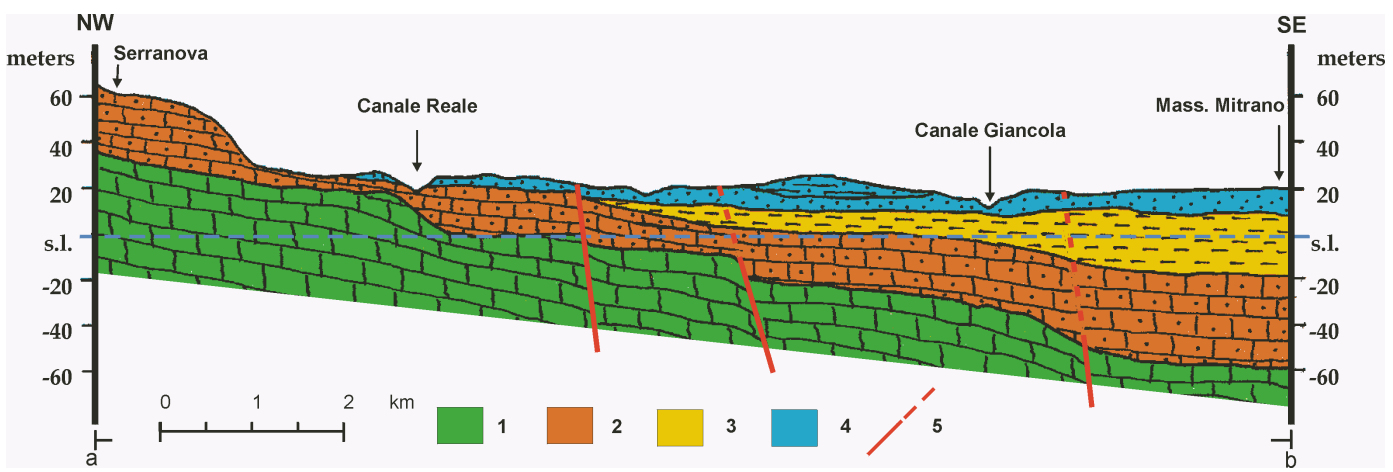

Fig. 2. Geological cross-section: 1) Limestones (Cretaceous); 2) Calcarenites (lower Pleistocene); 3) Marly clay (middle-upper Pleistocene); 4) Sands with interbedded calcarenites (upper Pleistocene); 5 Faults.

to the SSW where, because of the presence of more compact limestone, the water circulates under confined conditions.

Indeed, circulation inside the carbonate rock mass either in confined or unconfined conditions is subject to preferential flow pathways corresponding to fractures or to interconnected karst features that are have a larger capacity than other pathways with a significantly lower rate of permeability.

The resulting circuits affect the water heads, with high differences observed when the water levels are intersected along the carbonate rock mass.

Permeability in the rock formations is generally heterogeneously distributed. Where it is high, large volumes of water can be easily removed from the wells, whereas similar boreholes drilled at sites where permeability is low will only drain small amounts of water. This is obviously reflected by marine intrusion that is either enhanced or limited by the degree of communication with the sea.

Analysis of the morphology of the piezometric surface is for identifying the aquifer where groundwater drainage is more intense.

In an earlier work (Sciannamblo et al., 1994), we have demonstrated that there is an alternation between higher permeable levels and lower ones, according to strips about parallel and perpendicular to the coast-line.

We defined the hydraulic conductibility in the area by determining the "specific relative flows" resulting from several pumping tests carried out on wells, all recognised and classified as "incomplete", and then by using the expressions of Babouchkine-Guirinsky (Castany, 1963) in processing the data.

Hydraulic conductivity in the area varies from a minimum of $1 \times 10^{-6} \mathrm{~m} / \mathrm{s}$ to a maximum of $4 \times 10^{-2} \mathrm{~m} / \mathrm{s}$, and increases towards the coast as was predictable considering the lower thickness of the aquifer (Spizzico et al., 2004).

It should also be pointed out that even significant mass movements may be triggered in the aquifer as a result of extraction with significantly higher speeds. We would also like to highlight what is already known in literature (Castany, 1963) or that the normal underwater flow off speed of the aquifers increases in the vicinity of water drawing works, as a result of the extraction activity. The water of the deep

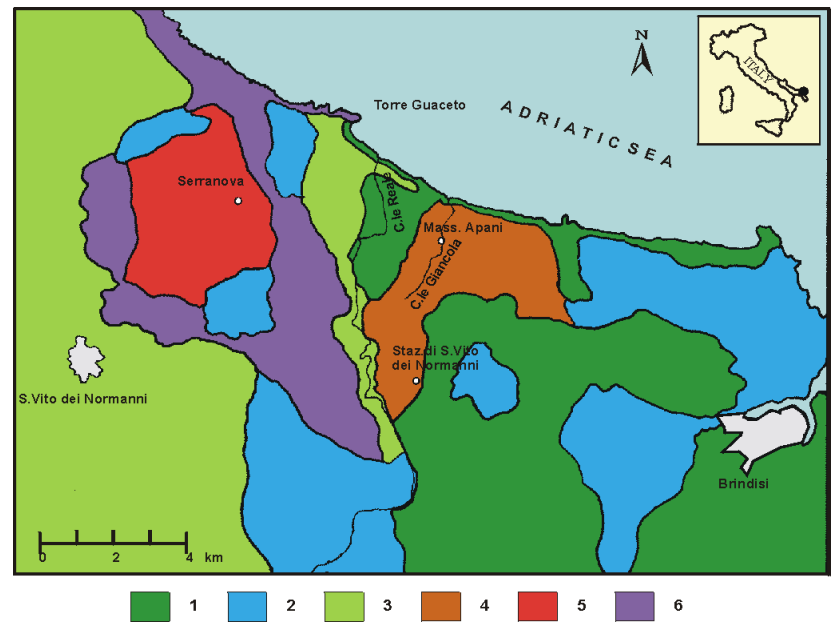

Fig. 3. Map of soils in the area of Torre Guaceto: 1) Sand and loamy sand; 2) Sandy clay loam, sandy clay and loam; 3) Clay and silty clay; 4) Calcareous sand; 5) Calcareous clay; 6) Calcareous soil.

aquifer, fed by rainwater falling in the innermost upland plain of Murgia, discharges to the sea following three main directions. Two of them converge in the coast and originate sub-aerial and submarine springs. The third one is oriented toward the morphologically depressed zone near the coast where the water emerges and flows freely to the sea.

Coastal discharges on average drain $300 \mathrm{l} / \mathrm{s}$, depending on daily and tidal changes in sea level; the same can be said for the natural depression operating as tidal basins.

The agricultural soils, sufficiently permeable and poor in organic matter (Lopez, 1971), with a coarse to medium texture, are mainly sands, loamy sands and loams (Fig. 3). They are mainly located over the central and south-eastern portion of the studied area. In the western there are also finer-grain soils, such as clayey and calcareous ones.

\section{Results of investigations}

In the area being investigated, thirty-six observation wells, all privately owned and all withdrawing the carbonate aquifer, 
Table 1. Values of some chemical and physical parameters of samples from the deep groundwater.

\begin{tabular}{|c|c|c|c|c|c|c|c|c|c|c|c|}
\hline $\begin{array}{l}\text { Wells } \\
\text { No. }\end{array}$ & $\begin{array}{c}\mathrm{T} \\
\left({ }^{\circ} \mathrm{C}\right)\end{array}$ & $\begin{array}{l}\text { TDS } \\
(\mathrm{g} / \mathrm{l})\end{array}$ & $\mathrm{pH}$ & $\begin{array}{c}\mathrm{Ca} \\
(\mathrm{mq} / \mathrm{l})\end{array}$ & $\begin{array}{c}\mathrm{Mg} \\
(\mathrm{mq} / \mathrm{l})\end{array}$ & $\begin{array}{c}\mathrm{Na} \\
(\mathrm{mq} / \mathrm{l})\end{array}$ & $\begin{array}{c}\mathrm{HCO}_{3} \\
(\mathrm{mq} / \mathrm{l})\end{array}$ & $\begin{array}{c}\mathrm{CO}_{3} \\
(\mathrm{mq} / \mathrm{l})\end{array}$ & $\mathrm{pHc}$ & $\operatorname{adjSAR}$ & $\begin{array}{c}\mathrm{NO}_{3} \\
(\mathrm{mq} / \mathrm{l})\end{array}$ \\
\hline 1 & 18.4 & 4.23 & 7.48 & 9.47 & 11.27 & 48.12 & 5.84 & - & 6.7 & 40.34 & 13.89 \\
\hline 2 & 19.1 & 1.31 & 6.95 & 6.53 & 3.20 & 12.95 & 5.79 & - & 6.8 & 15.27 & 23.07 \\
\hline 3 & 19.2 & 2.51 & 6.51 & 7.75 & 6.34 & 26.13 & 6.23 & - & 6.8 & 25.60 & 14.51 \\
\hline 4 & 18.3 & 1.79 & 6.48 & 7.29 & 4.22 & 17.64 & 5.9 & - & 6.9 & 18.38 & 27.28 \\
\hline 5 & 18.9 & 2.32 & 6.81 & 7.19 & 6.70 & 24.18 & 6.42 & - & 6.7 & 24.77 & 22.88 \\
\hline 6 & 18.3 & 1.48 & 6.97 & 6.94 & 3.46 & 13.50 & 5.18 & - & 6.9 & 14.80 & 98.03 \\
\hline 7 & 18.8 & 2.19 & 6.79 & 7.34 & 6.04 & 22.89 & 6.75 & - & 6.8 & 23.01 & 21.08 \\
\hline 8 & 19.6 & 1.51 & 6.87 & 7.34 & 3.92 & 13.68 & 6.76 & - & 6.8 & 14.98 & 8.12 \\
\hline 9 & 17.6 & 0.72 & 7.25 & 5.93 & 1.60 & 6.14 & 5.87 & - & 6.9 & 7.91 & 19.10 \\
\hline 10 & 18.2 & 2.54 & 7.20 & 7.09 & 8.02 & 25.72 & 7.1 & - & 6.7 & 25.27 & 18.17 \\
\hline 11 & 24.5 & 1.42 & 6.90 & 8.31 & 5.76 & 9.15 & 3.81 & - & 6.8 & 8.97 & 22.94 \\
\hline 12 & 21.5 & 1.24 & 7.08 & 6.18 & 3.16 & 11.68 & 5.14 & - & 6.9 & 13.51 & 44.71 \\
\hline 13 & 18.3 & 2.25 & 6.86 & 14.94 & 6.90 & 15.72 & 6.28 & - & 6.6 & 13.32 & 90.34 \\
\hline 14 & 19.3 & 3.43 & 6.70 & 8.31 & 9.50 & 38.32 & 6.44 & - & 6.7 & 34.67 & 21.52 \\
\hline 15 & 19.5 & 3.54 & 6.75 & 8.41 & 9.83 & 39.54 & 7.01 & - & 6.7 & 35.35 & 11.72 \\
\hline 16 & 20.0 & 1.14 & 7.20 & 6.99 & 2.91 & 10.36 & 5.5 & - & 6.8 & 12.11 & 48.92 \\
\hline 17 & 18.9 & 1.52 & 7.36 & 6.59 & 3.85 & 13.78 & 5.28 & - & 6.9 & 15.08 & 111.11 \\
\hline 18 & 19.1 & 3.04 & 6.60 & 13.98 & 11.77 & 25.11 & 4.83 & - & 6.7 & 18.90 & 74.28 \\
\hline 19 & 19.1 & 3.32 & 6.78 & 8.71 & 8.46 & 36.34 & 5.47 & - & 6.8 & 32.24 & 16.18 \\
\hline 20 & 21.2 & 2.99 & 7.25 & 8.00 & 8.44 & 32.06 & 6.74 & - & 6.8 & 29.07 & 10.48 \\
\hline 21 & 20.1 & 1.63 & 6.68 & 8.46 & 3.02 & 9.76 & 6.5 & - & 6.7 & 10.99 & 203.25 \\
\hline 22 & 19.7 & 4.27 & 6.68 & 13.32 & 8.43 & 51.72 & 7.18 & - & 6.7 & 42.35 & 399.81 \\
\hline 23 & 19.3 & 1.23 & 7.11 & 7.90 & 3.00 & 11.14 & 6.09 & - & 6.8 & 12.40 & 54.94 \\
\hline 24 & 19.5 & 2.42 & 7.15 & 6.99 & 8.77 & 24.28 & 6.4 & - & 6.8 & 22.49 & 51.09 \\
\hline 25 & 20.1 & 2.69 & 7.02 & 6.64 & 9.50 & 27.87 & 5.58 & - & 6.8 & 25.52 & 22.14 \\
\hline 26 & 22.5 & 2.52 & 7.80 & 10.28 & 7.95 & 24.36 & 7.35 & 0.44 & 6.6 & 22.59 & 12.03 \\
\hline 27 & 18.4 & 2.42 & 6.74 & 13.57 & 4.74 & 22.46 & 7.16 & - & 6.7 & 20.04 & 89.97 \\
\hline 28 & 19.9 & 4.63 & 7.25 & 10.13 & 14.53 & 61.24 & 7.04 & - & 6.6 & 48.84 & 7.63 \\
\hline 29 & 19.2 & 5.22 & 7.27 & 10.03 & 13.32 & 56.15 & 6.8 & - & 6.7 & 44.37 & 8.12 \\
\hline 30 & 18.6 & 7.04 & 7.10 & 10.89 & 19.22 & 80.24 & 6.8 & - & 6.5 & 59.97 & 5.02 \\
\hline 31 & 18.1 & 2.59 & 7.05 & 7.14 & 7.61 & 27.58 & 6.04 & - & 6.8 & 26.40 & 28.27 \\
\hline 32 & 19.6 & 1.41 & 6.78 & 10.89 & 1.53 & 11.02 & 5.35 & - & 6.8 & 11.50 & 168.53 \\
\hline 33 & 20.2 & 4.49 & 7.10 & 9.42 & 12.33 & 50.73 & 6.52 & - & 6.7 & 41.53 & 28.03 \\
\hline 34 & 21.4 & 4.33 & 6.98 & 8.26 & 12.66 & 50.40 & 6.54 & - & 6.7 & 42.08 & 14.26 \\
\hline 35 & 22.7 & 1.75 & 7.13 & 6.64 & 5.16 & 17.61 & 7.1 & - & 6.8 & 18.85 & 22.76 \\
\hline 36 & 26.2 & 7.42 & 7.32 & 9.17 & 21.06 & 87.01 & 2.6 & 0.24 & 6.8 & 58.19 & 12.40 \\
\hline
\end{tabular}

were studied. Sampling of deep groundwater was performed in these wells, always under pumping conditions.

The collected and processed data are shown in Table 1. In order to estimate water quality, some parameters such as temperature, $\mathrm{pH}$, salinity, were directly determined in situ, whilst others were determined in the laboratory.

Owing to the physical characteristics of soils in the zone, we considered necessary to evaluate the water quality using the Adjusted Sodium Adsorption Ratio, expressed by the following formula:

$\operatorname{adjS.A.R.}=\frac{\left[\mathrm{Na}^{+}\right]}{\sqrt{\frac{\left[\mathrm{Ca}^{++}\right]+\left[\mathrm{Mg}^{++}\right]}{2}}} \times\left[1+8.4-\mathrm{pH}_{c}\right]$.

It is well known that S.A.R. is extremely important for evaluating the water quality because it evidences the fact that the sodium which is contained in the water is likely to replace calcium and magnesium in the soil, thus worsening its chemical physical characteristics.

Adjusted S.A.R. differs from the traditional S.A.R. due to the introduction of a supplementary factor derived from $\mathrm{pH}$, surveyed and adjusted according to sodium, calcium, magnesium, carbonate and bicarbonate concentration in water. When $\mathrm{pH}_{c}$ exceeds 8.4, the water tends to dissolve carbonates present in the soil, while a $\mathrm{pH}_{c}$ below 8.4 indicates that the water tends to allow carbonate precipitation. Basically, the adjusting factor takes account of the increase in sodium concentration in the water due to the removal of calcium and magnesium ions caused by carbonate and bicarbonate precipitation.

Values of Adjusted S.A.R. were mapped in order to obtain aerial distribution over each period examined (Fig. 4); each 


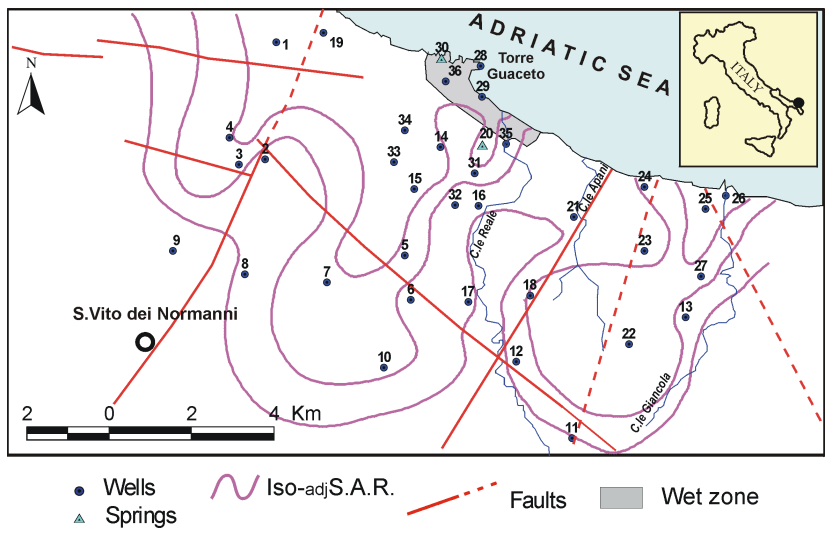

Fig. 4. Adjusted S.A.R. contours in deep groundwater. The State nature reserve of Torre Guaceto is shown in grey.

map included four classes of values of S.A.R. (Mi.P.A.F., 2001), that is: 1) adjS.A.R. $<=10$; 2) $10<$ adjS.A.R. $<18$; 3) $18<$ adjS.A.R. $<26 ; 4)$ adjS.A.R. $=>26$.

The maps show how adjS.A.R. 18, which represents the water quality critical threshold, deepens inland by forming two "pockets" whose extension varies according to the period examined.

The two "pockets", located in the central and south-eastern part of the area, are separated by "Canale Reale" whose course shows the main groundwater flow direction. Shape of the two "pockets" determines and characterises the coastal section and the preferential direction of seawater intrusion.

The reduction of water qualityis also confirmed by the presence of phosphates and ammoniac nitrous and nitric nitrogen in the water of some wells. This presence is mainly caused by the kind of cultivation (intensive), practised in some parts of the investigated area.

It has to be noted that the presence of phosphates and nitrogenous substances can be ascribed to the type of crops in the area, where more than $80 \%$ of the land is used for vegetable farming with a significant use of nitrogenous fertilizers. In the last few decades this consumption has increased so much that Apulia ranks first in Italy for use (about $86 \mathrm{~kg} / \mathrm{ha}$ ).

Even so, the peculiar geostructural features of the investigated area and in particular those of the SE sector, perform an important defensive action of the carbonate aquifer representing the only real water resource in Apulia.

Indeed, earlier studies have showed the presence, around the city of Brindisi, of a very thick layer of Calabrian (lower Pleistocene) marly clay, overlying a carbonatic basement (Spizzico et al., 2004). This stratigraphy determines particular hydrogeological conditions which favour the formation of a series of small groundwater systems overlying the deep groundwater.

Nowadays, these shallow groundwater systems, already widely used in the past, have a great importance for irrigation and as drinking water, even only during limited periods of the year.
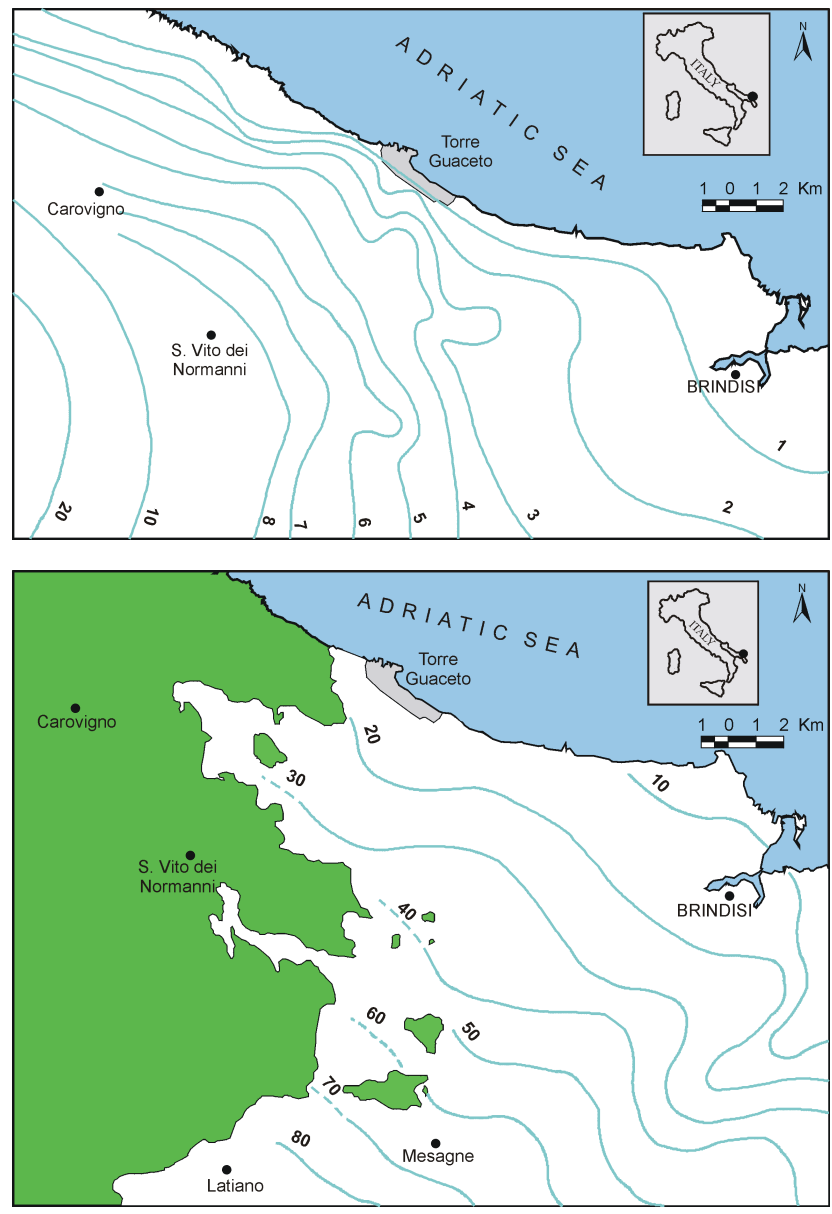

Fig. 5. Comparison between piezometric surfaces (in $m$ a.s.1.) of deep groundwater (top) and of shallow groundwater (bottom). Outcropping limestones are shown in green.

The piezometric surface (Fig. 5) of these shallow groundwater systems shows a mean SW-NE orientation of the discharge directions and a mean piezometric gradient of 3.5$3.8 \%$.

At the south-eastern margin of the studied area, the shallow groundwaters were sampled by means of hand-dug wells located near wells withdrawing from the carbonate aquifer. These samples were analysed to define their physical and chemical features (Table 2).

By comparing the water coming from the two different hydrogeological environments, we found two main features:

1. the shallow groundwater is fresher than the deep groundwater as results from a comparison of the salinity trends of the two hydrogeological systems (Fig. 6);

2. the protective function performed by the clay layer over the deep groundwater. In the case of nitrogenous compounds, we observed for example that at wells number 20, 25 and 26 in Table 1, the nitrate concentration was less than those measured in wells $b, f$ and $g$ in Table 2 .

In the second case, however, there are some exceptions due to the specific situations highlighted by shallow groundwater 
Table 2. Values of some chemical and physical parameters of samples from the shallow groundwater.

\begin{tabular}{cccccccccccc}
\hline $\begin{array}{c}\text { Wells } \\
\text { No. }\end{array}$ & $\begin{array}{c}\mathrm{T} \\
\left({ }^{\circ} \mathrm{C}\right)\end{array}$ & $\begin{array}{c}\mathrm{TDS} \\
(\mathrm{g} / \mathrm{l})\end{array}$ & $\mathrm{pH}$ & $\begin{array}{c}\mathrm{Ca} \\
(\mathrm{mq} / \mathrm{l})\end{array}$ & $\begin{array}{c}\mathrm{Mg} \\
(\mathrm{mq} / \mathrm{l})\end{array}$ & $\begin{array}{c}\mathrm{Na} \\
(\mathrm{mq} / \mathrm{l})\end{array}$ & $\begin{array}{c}\mathrm{HCO}_{3} \\
(\mathrm{mq} / \mathrm{l})\end{array}$ & $\begin{array}{c}\mathrm{CO}_{3} \\
(\mathrm{mq} / \mathrm{l})\end{array}$ & $\mathrm{pHc}$ & adjSAR & $\begin{array}{c}\mathrm{NO}_{3} \\
(\mathrm{mq} / \mathrm{l})\end{array}$ \\
\hline $\mathrm{a}$ & 20.0 & 0.24 & 7.95 & 2.69 & 0.27 & 0.41 & 3.25 & - & 7.5 & 0.63 & 1.86 \\
$\mathrm{~b}$ & 18.4 & 1.07 & 7.80 & 7.70 & 1.48 & 6.60 & 4.19 & - & 7 & 7.39 & 124.30 \\
$\mathrm{c}$ & 17.5 & 4.10 & 7.25 & 13.37 & 10.42 & 36.16 & 9.12 & - & 6.7 & 28.31 & 65.28 \\
$\mathrm{~d}$ & 16.8 & 1.60 & 7.34 & 11.59 & 2.96 & 13.70 & 4.78 & - & 6.8 & 13.21 & 106.70 \\
$\mathrm{e}$ & 19.9 & 1.53 & 7.20 & 9.83 & 2.53 & 11.76 & 5.67 & - & 6.7 & 12.78 & 49.31 \\
$\mathrm{f}$ & 17.8 & 2.31 & 6.95 & 11.40 & 5.11 & 20.55 & 5.88 & - & 6.7 & 19.31 & 255.00 \\
$\mathrm{~g}$ & 18.5 & 2.63 & 6.85 & 7.19 & 7.62 & 28.93 & 5.94 & - & 6.8 & 27.65 & 24.86 \\
$\mathrm{~h}$ & 19.8 & 2.11 & 6.90 & 7.95 & 5.20 & 21.58 & 4.51 & - & 6.9 & 21.04 & 71.24 \\
\hline
\end{tabular}
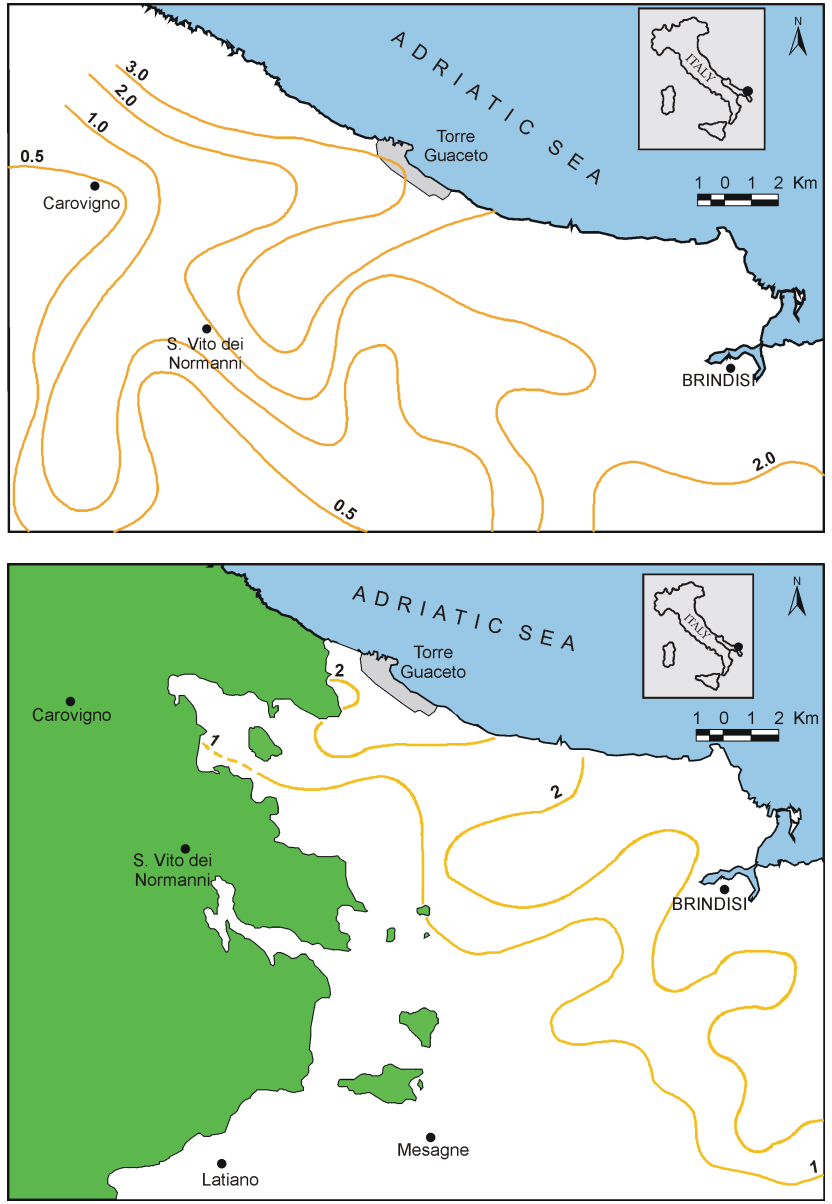

Fig. 6. Comparison between salinity contour (in $\mathrm{mg} / \mathrm{l}$ ) of deep carbonatic groundwater (top) and of shallow groundwater (bottom). Outcropping limestones are shown in green.

intrusion in the carbonate aquifer (e.g. wells number 21 and 22 of Table 1 and $c, d$ wells of Table 2). Among the many possible reasons for this discrepancy, bad bore-hole drilling reaching the carbonate aquifer and the discontinuous geometry of the clay layer might be invoked.

Analysis of nitrate concentration in the deep groundwater allowed us to draw up a map to evaluate spatial variations of salts in water (Fig. 7); it is well known that nitrates are very mobile due to both their solubility and their lack of interaction with the organic matter and with the soil particles. This implies that the quantity of nitrogenous fertilizers not absorbed by crops is partly exposed to transformation processes and partly leached by irrigation water and conveyed into groundwater.

Figure 7 shows that the area investigated is characterised by two large sectors, in the centre and in the south-eastern portion, respectively, where nitrate concentrations in water exceed $50 \mathrm{mg} / \mathrm{l}$, and at some points is more than $100 \mathrm{mg} / 1$. The two sectors are separated by the "Canale Reale" and have different extensions: the central sector is long and narrow, whilst the south-eastern is sub-circular and quite large. The south-eastern sector also includes almost all the area of outcropping of the sands. Investigations have also evidenced that more than $70 \%$ of the water sampled in this period has the M.A.C. (Maximum Allowable Concentration) of ammoniacal nitrogen, nitrites, nitrates, and phosphates exceeding those foreseen by the law.

\section{Conclusions}

The particular features of the Apulian carbonate aquifer and some aspects of its vulnerability have been studied in a coastal zone, part of which lies in a State nature reserve.

Analysis of the spatial variations of adjusted S.A.R. has allowed the determination of the main directions of intruding seawater, and characterised the fresh-water seawater imbalance caused by pumping water. Indeed, in the investigated area over $30 \%$ of supply water is being pumped, that is a very high percentage for a coastal aquifer.

Moreover,about $67 \%$ of the total withdrawal is water used for agriculture.

Under such conditions, the groundwater in the aquifer can only maintain its balance through gradual salinization from the seawater encroaching inland, both laterally and from below, causing an increase in the groundwater density and consequently a modification in the distribution of the piezometric heads. 
This aspect also shows how water is used without balancing the "Renewal rate", that is ignoring the hydrogeological characteristics of the area and thus the entity of the volumes of water which can be used to keep the resource in a balanced regimen. Rates of use and distribution of the wells should be defined according to the real availability of water in the area.

Deterioration of the deep groundwater quality is also due to anthropogenic pollution mainly deriving from agriculture.

Indeed, in this area, the south eastern sector is intensely farmed with the presence of greenhouses, nurseries and market gardens requiring significant use of nitrogenous agricultural fertilisers. Moreover, the area is characterised by mainly sandy soils (highly vulnerable), and by the presence of a small shallow groundwater system supported by clay levels.

This geological and structural setting creates a barrier to the direct supply of the deep aquifer and a natural obstacle to the diffusion of polluting elements in the carbonate acquifer. In spite of this, the localised presence of nitrates highlights the poor execution of the withdrawal systems which are located in the carbonatic aquifer; indeed the creation of these works often has the negative consequence of bringing the surface aquifers (more in direct contact with the agricultural soil) into contact with the deep aquifer.

This means that the shallow groundwater, often the source of significant pollutant loads, may migrate to the deep aquifer, thus impoverishing the quality of the resource: a simple and correctly made insulating cement blanket would have been sufficient to prevent this phenomenon (Tadolini et al., 1985; Bruno and Tadolini, 1989). In addition, it has to be stressed the lack of attention paid to the depth of wells dug in the area. Indeed, the users and above all the operators of the sector must be fully aware of the differences existing between "well potential" and "resource potential", a difference which, in the long term, becomes of fundamental importance in maintaining the quality of a coastal aquifer.

Finally, the study highlights the fact that carbonate groundwater is significantly affected by anthropogenic impact, mainly related to agricultural practices.

The situation depicted so far is destined to get even worse unless work and programmes to safeguard and correctly manage the water resource are carried out. All this, in spite of the fact that laws already exist on the matter although they are generally disregarded or not applied.

At the same time, it is necessary to start a series of initiatives aimed at improving the quality of the water in the area. To such a purpose it is advisable to awaken the public opinion on the consumption control which should be in line with the "renewal rate" of the water resource. Moreover, more care must be taken over locating and executing pumping works, and agricultural practice must respect the particular hydrological features of the region to help improve water quality.

Acknowledgements. we would like to thank M. Clark for his help in drawing up the English version of this paper.

Edited by: M. Parise

Reviewed by: two referees

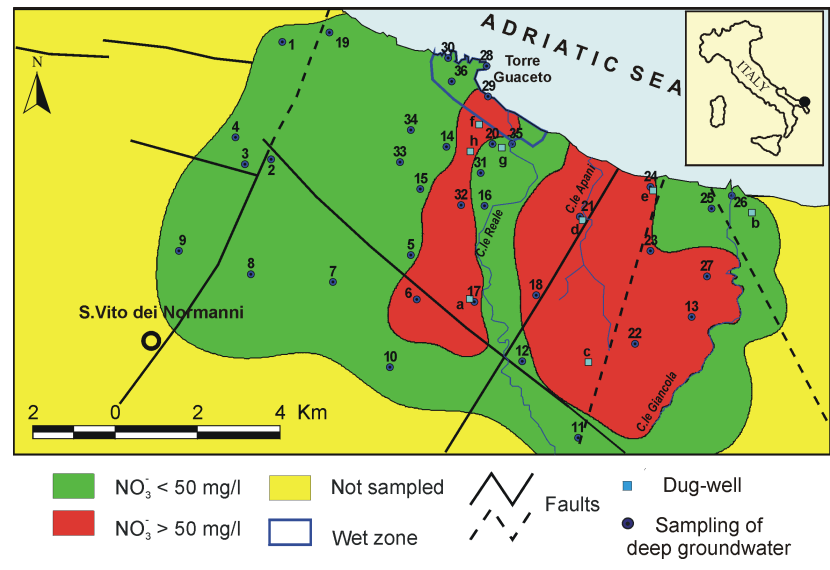

Fig. 7. Distribution of nitrate concentrations in the deep carbonate aquifer.

\section{References}

Bruno, G. and Tadolini, T.: Hydrogeological features and implication of tectonic and structural traits upon salentine aquifers (Apulia, Southern Italy). Congr. Int. Geoingegneria SOTTOSUOLO, Ass. Min. Subalp., 1, 441-448, Torino, 1989

Castany, G.: Trattè pratique des eaux souterraines, Dunod Ed., Paris, 1963.

Ciaranfi, N., Pieri, P., and Ricchetti, G.: Note alla carta geologica delle Murge e del Salento (Puglia centromeridionale), Estr. Mem. Soc. Geol. It., 41, 449-460, 1992.

Cotecchia, V.: Studies and investigations on apulian groundwaters and intruding seawaters (Salento Peninsula), C.N.R.-I.R.S.A., 20, 1977.

Dell'Anna, L.: Ricerche su alcune terre rosse della Regione Pugliese, Estr. Periodico di mineralogia, 36, 2, 1967.

Edlmann, L.: Alcune considerazioni sulle terre rosse. Bol. Soc. Geol. It., 66, 1947.

Grassi, D.: Il carsismo della Murgia (Puglia) e sua influenza sull'idrogeologia della regione, Geol. Appl. e Idrogeol., 9, 119190, 1974

Grassi, D. and Tadolini, T.: L'acquifero carsico della Murgia nordoccidentale (Puglia). Geol. Appl. e Idrogeol., 9, 39-57, 1974.

Grassi, D. and Tadolini, T.: Hydrogeology of the mesozoic carbonate platform of Apulia (South Italy) and the reasons for its different aspects. International Symposium on karst water resources Ankara, 1985.

Grassi, D., Tadolini, T., Tazioli, G. S., and Tulipano L.: Ricerche sull'anisotropia dei caratteri idrogeologici delle rocce carbonatiche mesozoiche della Murgia nord - occidentale, Geol. Appl. e Idrogeol., 12, 187-213, 1977.

Lopez, G.: Studio dei terreni agrari della provincia di Brindisi, Estr. Annali Ist. Sper. Agr., 2, 2, 10, 1971.

Mi.P.A.F. - Ministero delle Politiche Agricole e Forestali: Metodi di analisi delle acque per uso agrario e zootecnico, Coord. G. Mecella, Franco Angeli Ed., Roma, 2001.

Sciannamblo, D., Spizzico, M., Tadolini, T., and Tinelli, R.: Lineamenti idrogeologici della zona umida di Torre Guaceto $(\mathrm{Br})$, Estr. Geologica Romana, 30, 755-760, 1994.

Sinno, R.: Studio sulle terre rosse dell'Italia centrale e meridionale. La terra rossa di Gaeta, Boll. Soc. Nat. Napoli, 72, 1964.

Spizzico, M., Lopez, N., and Sciannamblo, D.: Applicazione del 
metodo SINTACS all'acquifero costiero pugliese, Atti XXIX ${ }^{\circ}$ Convegno di Idraulica e Costruzioni Idrauliche, Trento, 2, 641649, 2004.

Tadolini, T., Calò, G., Spizzico, M., and Tinelli, R.: Caratterizzazione idrogeologica dei terreni post cretacei presenti nell'area di S. Cesario di Lecce, $5^{\circ}$ Congr. Int. sulle Acque Sotterranee, Taormina, 1985.

Tadolini, T., Spizzico, M., and Sciannamblo, D.: Time corse of radon concentration in the deep karstic aquifer of the coastal belt North-East of San Vito dei Normanni (Brindisi - Italy), Proceedings of the $13^{\circ}$ Salt-water Intrusion Meeting, Cagliari, 1994.
Tadolini, T., Spizzico, M., and Sciannamblo, D.: Variazioni di concentrazione del radon nelle acque di una sorgente costiera subaerea a nord di Brindisi, Estr. Mem. Soc. Geol. It. 51, 989-993, 1996.

Zezza, F.: Le facies carbonatiche della Puglia e il fenomeno carsico ipogeo, Geol. Appl. e Idrogeol., 10, 1-54, 1975. 